\title{
An Analysis of the Risk of Anemia on Female Students of Senior High School Number 6 Palembang

\author{
$1^{\text {st }}$ Sartono \\ Departement of Nutrition \\ Palembang, Indonesia
} \\ Politeknik Kesehatan Palembang \\ sartonogz@gmail.com

\author{
$2^{\text {nd }}$ Ahmad Sadiq \\ Departemen of Nutrition \\ Politeknik Kesehatan Palembang \\ Palembang, Indonesia \\ ahmadsadiqabbas@yahoo.com
}

Coreespondent Author: sartonogz@gmail.com

\begin{abstract}
The result of Baseline Health Research (Riskesdas) 2013 was found out that iron nutritional anemia is still being public health problems with prevalence $\geq 20$ percent in adolescents. Anemia iron nutrition is still a public health problem with prevalence in adolescents of 13- 18 years and 22.7 percent (RI Ministry of Health, 2013). The purpose of this research was to find out the analysis of the risk of anemia to the students of Senior High School Number 6 Palembang. The type of this research used was research analytic survey through screening with case control design by comparison 1: 1 and matching to age. The population in this study was all of the class XI of Senior High School Number 6 Palembang with the total number 188 students, while the research sample was selected students based on the criteriaof88 female students, taken as proportionally Stratified Random Sampling. The anemia data was obtained by taking respondents' venous blood by laboratory personnel, protein intake data, $\mathbf{F e}$ intake, Vitamin $\mathrm{C}$ intake, fiber intake obtained using the SQFFQ form, and the data of tea drinking habits in a day obtained through the direct interviews using a questionnaire taken by Experts Nutrition Analysis of the data used was univariate analysis, bivariate analysis and multivariate analysis. A statistical test used in bivariate analysis and multivariate was test $C$ hi Square. The whole processing data in a manner done in a computerized. The results screening obtained anemia prevalence at female high school students was $37.2 \%$. While the results of statistical tests showed there was a significant relationship between substance intake iron (Fe) with a risk of anemia $(p=0.053)$ with an $O R$ value of 2.57 , it showed that female students who was intake insufficient substances iron from recommended adequacy had a 2.57 times chance to experience anemia. And there was a meaningful relationship between protein intake with risk of anemia $(p=0.001)$ with OR value $=8.60$, it showed that the students whose protein intake was not sufficient from the recommended
\end{abstract}

adequacy had 8.60 times the chance to experience anemia.

Keywords: Anemia, Iron, Protein, Vitamin C, Fiber, Drinking Tea.

\section{INTRODUCTION}

Hemoglobin is a parameter widely used for setting anemia prevalence [1], Citrakesumasari (2012) says that teens are at high risk suffer from anemia, especially lack of iron because teenagers are experiencing a growth very fast. In growth, the body needs a lot of nutrition, and among them are iron. If iron which is used for growth is less than produced by the body, the anemia happens [2].

The 2013 Riskesdas result shows that iron nutritional anemia is still a public health problem with the prevalence number of iron nutrient anemia in female adolescents of 13-18 years by 22.7 percent at over the threshold of health problems for iron nutritional anemia [3]. Sartono's research results (2016) at 72 first-level students at six majors on Health Polytechnic of Ministry of Health of Palembang obtained 59.7\% with the anemia status, and the largest percentage is in Department of Nutrition at 86.7\% (13 people from 15) [4].

The incident of anemia that often found in Indonesia, namely anemia caused by the production of inadequate red blood cells, caused by nutrient consumption factors, especially iron. As a result, someone suffers malnutrition, especially iron [5]. Anemia also occurs because of some things, among them an imbalance in nutrient intake can cause anemia in adolescents too, if 
the food intake is less then the much iron will be demolished. Things like this can accelerate anemia [6]. According to De Maeyer (1995), protein plays an important role in the transportation of iron inside of the body. Therefore, lack of protein intake will result to the blocked iron substances transportation that can cause iron deficiency [7]. The exaggerated tannin compounds from tea in blood will interferes the iron absorption. The body iron deficiency hence the formation of red grains blood (hemoglobin) being reduced resulting in anemia. An influence tannin inhibition can be avoided by not drinking tea after eating as not interfering the substance iron absorption [8]. Sources that inhibits the absorption of iron are varies. The fiber in vegetables could inhibits absorption of non-heme iron. If tea (containing tannin) is consumed with food, it will reduce the iron absorption. Drinking a tea when eating will decrease the iron absorption to 50 percent. Coffee, and milk products also inhibits heme absorption [9].

According to Soekirman (2000) that iron nutritional anemia in adolescents can cause various impacts, among others are decreasing stamina as susceptible to contaminated by disease and decreasing activities related to physical work abilities and learning achievement [10]. Senior High School Number 6 Palembang with a very dense learning system between learning and practical hours along with extracurricular activities ask students to stay fit and healthy to be able to complete education on time demanding the students to study for a long time inside and outside the classroom, but not many students can access food in the school environment well.

\section{METHODS}

This research was conducted in Senior High School Number 6 Palembang in Sersan Sani Street, Basuki Rahmat, Kemuning District. The targeted students was from class XI MIA and IPS with an age range of 15-19 years. The research was held from September to December 2019.This research was analytic survey research with Case Control design. The number of samples taken into control must be the same as number of case samples, by comparison 1: 1, which was previously matched with respect to age [11]. The population of this study was all of class XI MIA and IPS students aged15-19 years old registered in Senior High School Number 6 Palembang, in total 188 students. The samples of this research was class XI MIA and IPS students as manyas 88 students with characteristics as follows: a). The female students of Senior High School Number 6 Palembang with age range 15-19 years old. b). The ones who are not menstruating. c) Registered as students at the time of research. d). Ready be a research sample during the study takes place. e). Had willingness of blood being taken in measuring hemoglobin levels.

The research instrument used includes semiquantitative food Frequency question (SQFFQ) forms to get iron, protein, vitamin $\mathrm{C}$, and fiber [12]. While the questionnaire instrument was only used to get data on drinking habits. And Haemometer digital used to get anemia prevalence data on female students. The anemia prevalence data collection technique was done by taking respondents' venous blood specimens whose $\mathrm{Hb}$ levels was checked by Laboratory Staff Health Analyst during morning break between 09.00-10.00 WIB. The data intake of iron, protein, vitamin $\mathrm{C}$, fiber and tea drinking habits was taken through direct interviews conducted by Nutritionist during the afternoon break after Midday prayer. Data processing was done by computerized using spss software, while the statistical tests used was chi square.

\section{RESULTS}

The samples of this study was the students of Class XI MIA and IPS of Senior High School Number 6 Palembang with a number of learning classes as many as 10 classes consisting of 7 MIA classes and 3 IPS classes with a total number of 88 female students spread over MIA class as 64 students $(72.7 \%)$ and IPS class of 24 students $(27.3 \%)$, with a sample age range between 16-17 years distributed in the age group 16 years as 36 students $(40.9 \%)$ and age 17 years as 52 female students $(59.1 \%)$. While a general description of upper arm circumference (LILA) and nutritional status based on body mass index according to sample age showed as 29 students $(33.0 \%)$ experiencing chronic energy shortages (KEK) and 59 students $(67.0 \%)$ did not KEK, whereas for the nutritional status of female students, there was 2 thin female students $(2.3 \%)$ nutritional status, 61 normal female students $(69.3 \%)$ nutritional status, 16 fat students (18.2\%) nutritional status and 9 students (10.2\%) nutritional status of obesity.

\section{A. Univariate Analysis}

\section{Prevalence of Anemia}

The blood specimen examination results against 188 students of Class XI of Senior High School Number 6 Palembang obtained 37.2\% (70 students) having anemia.

2. Nutrient Intake (Iron, Protein, Vitamin C and Fiber) The results of continuous data analysis of substance intake iron obtained an average value of 
$13.62 \mathrm{mg}$ per day with a minimum value of $4.30 \mathrm{mg}$ and a maximum value of $55.50 \mathrm{mg}$. For intake the protein obtained an average value of 74.13 grams per day with a minimum value of 30.70 grams and a maximum value of 150.10 grams. And for Vitamin C intake the average value was obtained average intake of $94.30 \mathrm{mg}$ per day with a minimum value of 16.30 $\mathrm{mg}$ and a value a maximum of $456.70 \mathrm{mg}$.

Table 1. Respondent Frequency Distribution According To Nutrition Intake

\begin{tabular}{lcl}
\hline Nutrient Intake & $\mathbf{n}$ & \% \\
\hline Iron : & & \\
\hline Not enough & 50 & 56.8 \\
\hline Enough & 38 & 43.2 \\
\hline & 88 & 100 \\
\hline Protein: & & \\
\hline Not enough & 20 & 22.7 \\
\hline Enough & 68 & 77.3 \\
\hline & 88 & 100 \\
\hline Vitamin C : & & \\
\hline Not enough & 27 & 30.7 \\
\hline Enough & 61 & 69.3 \\
\hline & 88 & 100 \\
\hline Fiber: & & \\
\hline Not enough & 83 & 94.3 \\
\hline Enough & 5 & 5.7 \\
\hline & 88 & 100 \\
\hline
\end{tabular}

The results showed that most respondents' iron intake was not enough as many as 50 students (56.8\%). For protein intake mostly enough intake of respondents was 68 students $(77.3 \%)$, and for Vitamin C intake some of the respondents had sufficient intake as many as 61 students $(69.3 \%)$, while for fiber intake of most respondents insufficient intake was 83 students (94.3\%).

\section{Tea Drinking Habits}

The results of continuous data analysis was the average value of tea drinking habits on female students 3.51 times per week with minimum value was 0 and the maximum value was 14 times a week. To be clearer, the distribution of tea drinking habits to students can be seen in Table 2.
Table 2. Respondent Frequency Distribution According To Tea Habits

\begin{tabular}{lcc}
\hline Tea Drinking Habits & n & \% \\
\hline Not good & 4 & 4.5 \\
\hline Good & 84 & 95.5 \\
\hline Total & 88 & 100 \\
\hline
\end{tabular}

The results showed that a large part of respondents had a good drinking habits tea as many as 84 students $(95.5 \%)$.

\section{B. Bivariate Analysis}

1. The Relationship between Iron Intake and Hemoglobin Level

Table 3 shows that the female students whose the iron intake was not enough found in anemic group that was $68.2 \%$ compared to the group of female students with normal hemoglobin levels that was only $45.5 \%$. The statistic test result shows that the value of $p=0.053$, which indicates a meaningful relationship between iron intake and hemoglobin level with Odd Ratio value $(O R)=2.57$. It shows that a female student whose intake of iron was insufficient from her needs had opportunities risk of 2.57 time to experiencing anemia compared to the one whose intake of substances iron was sufficient.

Table 3 The Frequency Distribution of Hemoglobin Level according To Iron Substance

\begin{tabular}{|c|c|c|c|c|}
\hline \multirow{2}{*}{$\begin{array}{l}\text { Iron } \\
\text { Intake }\end{array}$} & \multicolumn{2}{|c|}{ Hemoglobin Level } & \multirow[t]{2}{*}{ Total } & \multirow{2}{*}{$\begin{array}{l}\text { P/OR } \\
\text { Value }\end{array}$} \\
\hline & Anemia & Normal & & \\
\hline \multirow{2}{*}{$\begin{array}{l}\text { Not } \\
\text { enough }\end{array}$} & 30 & 20 & 50 & \multirow{6}{*}{$\begin{array}{l}0.053 \\
\text { OR } \\
2.75 \\
(1.079- \\
6.130)\end{array}$} \\
\hline & $(68.2 \%)$ & $(45.5 \%)$ & $(56.8 \%)$ & \\
\hline \multirow[t]{2}{*}{ Enough } & 14 & 24 & 38 & \\
\hline & $(31.8 \%)$ & $(54.5 \%)$ & $(43.2 \%)$ & \\
\hline \multirow[t]{2}{*}{ Total } & 44 & 44 & 88 & \\
\hline & $(100 \%)$ & $(100 \%)$ & $(100 \%)$ & \\
\hline
\end{tabular}

2. The Relationship between Protein Intake and Hemoglobin Level

Table 4 shows that the female students whose protein intake was not enough found in anemic group of female students of $38.6 \%$ compared with a group of female students with normal hemoglobin levels as $6.8 \%$. The statistical test results shows the value of $p=$ 0.001 , indicating a meaningful relationship between protein intake and hemoglobin level with the value of $O R=8.60$ shows that the female students whose not enough protein intake from their daily needs had an 
relationship between iron intake and anemia $(\mathrm{p}=$ 0.002) [14].

The female students whose protein intake was not enough in the group of anemia was caused due to the food sources containing more plant proteins such as tempeh $(48.7 \%)$ and tofu $(32 \%)$, and the rest was from animal proteins. In fact, the food sources of plant proteins have less biological value in protein metabolism of the body compared to food sources containing animal proteins that is easily absorbed [2]. And the result of this research is in line with the results of the study conducted by Sartono (2016) on Female students of Health Polytechnic of Ministry of Health of Palembang which states that there is a relationship between protein intake with the anemia $(p=0.042)$ [4], also the results of Novitasari's research (2014) concerning the relationship among protein intake level, iron, vitamin $\mathrm{C}$ and zinc with hemoglobin levels in female students in Senior High School Batik I Surakarta $(p=0,000)$ [14]. This is matter in accordance with the theory put forward by Linder (2010) that one of the protein functions is to play a role in iron transportation into the bone marrow to form new hemoglobin molecules, and the iron is an important element of the body and is required for the production of red blood cells. If the iron is insufficient in the body, the iron that is stored in the body will be used. If the iron deposits gone, the body will lack of red blood cells and the amount of hemoglobin inside of it will reduce resulting in anemia [13].

It is known that insufficient vitamin $\mathrm{C}$ intake of the respondents happened due to the low percentage amount of intake that is consumed, with less of variety such as oranges $(21.3 \%)$, papaya $(20.4 \%)$ and bananas $(18.7 \%)$ which time is too long from the main course time. Lack of vitamin $\mathrm{C}$ intake will reduce absorption of non-hemic iron so that non-hemic iron in the intestine is difficult to be absorbed from ferric bonds into ferrous bonds [13]. This is in line with the results of the research conducted by Sartono (2016) about vitamin $\mathrm{C}$ intake with anemia status in female students of Health Polytechnic of Ministry of Health of Palembang where the results shows that there was no meaningful relationship between vitamin $\mathrm{C}$ intake and hemoglobin level $(p=0.43)$ [4].

In this study, it is known that the fiber intake had an influence on anemia status. It happens because there are factors that influence the anemia in respondents with less fiber intake with the average respondents who often consume water soluble fiber like carrots $(39.3 \%)$ and water pumpkin $(13.5 \%)$ compared to insoluble fiber, and also it is affected by lack of knowledge about anemia. And lack of fiber from food can be resulting in disruption in the disposal process of leftovers from the intestine, and constipation occurs. But, an excessive consumption of fiber can reduce the absorption of vitamins and minerals that will continue in the control of iron absorption [2]. This is in line with the results of the research conducted by Hidayanti (2014) in women preconception in the City of Makassar mentioning that there was no significant relationship between fiber consumption and hemoglobin level $(p=0.442)$ [9]. And the research result conducted by Kirana (2011) to the female students from Senior High School Number 2 Semarang mentioning that there was no meaningful relationship between hemoglobin level and fiber intake of the female students. $(p=0.252)[6]$.

In this study, it is known that even though most of students had a good tea drinking habit with the frequency $\leq 7$ times a week, however when it was related to students' time behavior in consuming tea with a distance drinking time is less than one hour before or after eating, even more drinking tea while eating the main course. The female students consume a lot of types of green tea $(59.5 \%)$ and black tea $(31.0 \%)$ with a type of sugary tea and packaged drinks like The Botol Sosro, The Kotak, and Nu Green Tea. This is in line with the statement stated by Linder (2010) that one factor affects the absorption of iron is tannin that is contained in tea which capable of decreasing the iron absorption. Consuming tea one hour after eating will decrease absorption of iron up to $85 \%$ because it contains a polyphenol substance such as tannin [13].

\section{CONCLUSION}

The anemia prevalence of female students in Senior High School Number 6 was 37.2\%. Most of female students' iron $(\mathrm{Fe})$ intake was not enough, equivalent to $56.8 \%$. Most of female students' protein intake (77.3\%) and vitamin C intake $(69.3 \%)$ was enough. Some of female students' fiber intake was not enough, equivalent to $94.3 \%$. The tea drinking habit of female student was good, equivalent to $95.5 \%$. The female students whose iron intake was not sufficient had an opportunity risk of anemia 2.57 times compared to the female students whose iron intake was good. And the female students whose protein intake was inadequate had an opportunity risk of anemia 8.60 times compared to those who had good protein intake. There was no meaningful relationship among vitamin $C$ intake $(p=0.355)$, fiber intake $(p=1,000)$ and tea drinking habit $(\mathrm{p}=0.116)$ with hemoglobin level in female students of Senior High School Number 6 Palembang. 


\section{ACKNOWLEDGMENT}

The author is grateful to Director of Health Polytechnic Palembang, Head of the Nutrition Department of Health Polytechnic Palembang, and The ICoHSST Committee for the conference.

\section{REFERENCES}

[1] Novitasari S. Relationship Level of Protein Intake, Iron, Vitamin C And Zinc With Levels Hemoglobin in Young Women In SMA Batik 1 Surakarta. 2014;7:219-32.

[2] Citrakesumasari. Nutritional Anemia, Problem and Prevention. Yogyakarta: Kalika; 2012. https://doi.org/10.22146/jnteti.v6i3.340.

[3] Health RM of. Presentation of Principal Principal Results of Basic Health Research 2013. Jakarta: Indonesian Research and Development Agency; 2013.

[4] Sartono and Nilawati N. The Risk Factor that related to Anemia to the students of Health Polytechnic, the Ministry of Health of Palembang in 2016. Palembang: The Palembang Health Polytechnic of Health Ministry; 2016. https://doi.org/10.1177/109019817400200403.

[5] Anwar F. Eat right, Healthy body. Jakarta: Wisdom; 2009.

[6] Kirana DP. The Relationship of Nutrient Intake and Pattern Menstruation WithAnemia in Female Students in SMAN 2 Semarang (E-Articles Research). Semarang: The University Diponegoro.; 2011.

[7] Maeyer D. Preventing and controlling iron deficiency anaemia through primary health care: a guide for health administrators and programme managers. Jakarta: WidyaMendika; 1995

[8] Wake Up EB, Lubis Z, Albiner S. Perilaku minum teh dan kadar Hemoglobi $(\mathrm{Hb})$ pada siswa-siswi Sekolah Menengah Kejuruan Negeri 1 Jorlang Hataran Desa Dolok Marlawan Kecamatan Jorlang Kabupaten Simalungun Tahun 2012. Kesehatan Reproduksi Dan Epidemiol 2012;2:1-6.

[9] Hidayanti, Farida; Thaha, AR; Najamuddin U. The Overview of Consumption Pattern of Inhibitors and Emitters of Iron $(\mathrm{Fe})$ Absorption and Hb Levels in Women Preconception in the City of Makassar. Makassar: Nutrition, Faculty Health TheHasanuddin University.; 2014. https://doi.org/10.1177/1755738014535565.

[10] Arumsari. Risk Factors for Anemia In the Young Women Participants in the Program Prevention and Prevention Iron Nutrition Anemia in the City of Bekasi. Institute Bogor Agriculture, 2008. https://doi.org/10.25182/jgp.2011.6.1.7483 .

[11] Sudigdo Sastroasmoro SI. Dasar-dasar metodologi penelitian klinis. Jakarta: Sagung Seto; 2014 https://doi.org/https://doi.org/10.1016/j.jvoice.2013.08.014.

[12] Gibson RS. Principles of nutritional assessment. vol. 4 Newyork: Oxford : Oxford University Press; 2005.

[13] Linder MC. Biokimia nutrisi dan metabolisme: dengan pemakaian secara klinis. Jakarta: UI-Press; 1992. https://doi.org/10.33853/istighna.v1i1.20. 